University of Nebraska - Lincoln

DigitalCommons@University of Nebraska - Lincoln

$2-1-2006$

\title{
Chinch Bug (Hemiptera: Blissidae) Mouthpart Morphology, Probing Frequencies, and Locations on Resistant and Susceptible Germplasm
}

\author{
Wyatt G. Anderson \\ University of Nebraska-Lincoln \\ Tiffany Heng-Moss \\ University of Nebraska-Lincoln, thengmoss2@unl.edu \\ Frederick P. Baxendale \\ University of Nebraska-Lincoln, fbaxendale1@unl.edu \\ Lisa M. Baird \\ University of San Diego, Baird@sandiego.edu \\ Gautam Sarath \\ University of Nebraska-Lincoln, Gautam.sarath@ars.usda.gov \\ See next page for additional authors \\ Follow this and additional works at: https://digitalcommons.unl.edu/usdaarsfacpub \\ Part of the Agricultural Science Commons
}

Anderson, Wyatt G.; Heng-Moss, Tiffany; Baxendale, Frederick P.; Baird, Lisa M.; Sarath, Gautam; and Higley, Leon G., "Chinch Bug (Hemiptera: Blissidae) Mouthpart Morphology, Probing Frequencies, and Locations on Resistant and Susceptible Germplasm" (2006). Publications from USDA-ARS / UNL Faculty. 38.

https://digitalcommons.unl.edu/usdaarsfacpub/38

This Article is brought to you for free and open access by the U.S. Department of Agriculture: Agricultural Research Service, Lincoln, Nebraska at DigitalCommons@University of Nebraska - Lincoln. It has been accepted for inclusion in Publications from USDA-ARS / UNL Faculty by an authorized administrator of DigitalCommons@University of Nebraska - Lincoln. 


\section{Authors}

Wyatt G. Anderson, Tiffany Heng-Moss, Frederick P. Baxendale, Lisa M. Baird, Gautam Sarath, and Leon G. Higley 


\title{
Chinch Bug (Hemiptera: Blissidae) Mouthpart Morphology, Probing Frequencies, and Locations on Resistant and Susceptible Germplasm
}

\author{
WYATT G. ANDERSON,${ }^{1}$ TIFFANY M. HENG-MOSS,${ }^{1}$ FREDERICK P. BAXENDALE ${ }^{1}$ \\ LISA M. BAIRD ${ }^{2}$ GAUTAM SARATH,${ }^{3}$ AND LEON HIGLEY ${ }^{1}$
}

\begin{abstract}
J. Econ. Entomol. 99(1): 212-221 (2006)
ABSTRACT Chinch bugs are common pests of many agronomic and horticulturally important crops and turfgrasses. Previous research has indicated that some grasses exhibit resistance to multiple chinch bug species, whereas others are resistant to only one species. The objectives of this research were to document differences in the probing frequencies and locations among Blissus species as well as differences in mouthpart morphology as a first step in understanding the differential responses of grasses to chinch bug feeding. Scanning electron microscopy detected differences in the total lengths of proboscises as well as individual mouthpart segments among the four species studied. Blissus occiduus Barber probed significantly more often on buffalograss, Buchloë dactyloides (Nuttall) Engelmann, than any other plant material. Probing locations of B. occiduus and Blissus leucopterus leucopterus (Say) were similar on both B. occiduus-resistant and susceptible buffalograsses and KS94 sorghum, Sorghum bicolor (L.) Moench (B. occiduus-resistant, B. l. leucopterus-resistant). However, on 'Wheatland' sorghum (B. occiduus-resistant, B. l. leucopterus-susceptible), stylet tracts of B. l. leucopterus most often terminated in the bundle sheath cells, whereas those of B. occiduus generally terminated in the vascular tissues.
\end{abstract}

KEY WORDS chinch bug, Blissus, plant resistance, turfgrass, sorghum

IN the United States, four species of chinch bugs (Hemiptera: Blissidae: Blissus) are of major economic importance: the chinch bug, Blissus leucopterus leucopterus (Say); the southern chinch bug, Blissus insularis Barber; the hairy chinch bug, Blissus leucopterus hirtus Montandon; and the western chinch bug, Blissus occiduus Barber (Vittum et al. 1999). Although closely related, these chinch bugs have been shown to elicit differential feeding responses in their grass hosts (Anderson 2004). For example, 'Prestige' buffalograss, Buchloë dactyloides (Nuttall) Engelmann, which has documented resistance to $B$. occiduus, is apparently susceptible to all of the other chinch bug species evaluated. Conversely, several grasses that are susceptible to B. l. leucopterus, B. l. hirtus, and B. insularis are resistant to B. occiduus (Anderson 2004). As a first step toward understanding the mechanisms responsible for the differential responses of grass hosts to chinch bug feeding, an investigation of chinch bug mouthpart morphology as well as the probing frequencies and locations was conducted on resistant and susceptible grasses.

Although a significant number of Hemiptera are phytophagous, and many are economically important pests, the mouthpart morphology and feeding behav-

\footnotetext{
${ }^{1}$ Department of Entomology, University of Nebraska, Lincoln, NE 68583.

${ }^{2}$ Department of Biology, University of San Diego, San Diego, CA 92110.

${ }^{3}$ USDA-ARS, University of Nebraska, Lincoln, NE 68583.
}

ior of these insects have not been thoroughly studied (Backus 1988). This is especially true for chinch bugs. Not since Painter (1928) investigated the feeding mechanisms of B. l. leucopterus on sorghum, Sorghum bicolor (L.) Moench, have chinch bug mouthparts been closely examined. Painter noted that, like other Hemiptera, the chinch bug stylets lie in a groove in the labium when at rest. The mandibular portion of the stylets are barbed at the distal end, whereas the maxillary stylets are pointed sharply and when pressed together form two canals: a suction (dorsal) canal and an ejection (ventral) canal. This four-segmented proboscis is used to carry secretions into the plant tissue from the salivary pump and plant sap back to the chinch bug (Painter 1928). Similar piercing-sucking mouthpart structures and functions have been described for other sap-feeding insects (Parrish 1967, Saxena and Chada 1971, Backus and McLean 1982). Furthermore, several researchers (Backus and McLean 1982, 1985; Walker and Gordh 1989) have identified the apical labial sensilla of sapfeeding insects as important chemo- and mechanoreceptors in host selection and feeding.

Differential responses of resistant and susceptible grasses to feeding by different chinch bug species suggests variations in mouthpart morphology, probing behavior, and feeding locations may exist within the Blissus complex. Therefore, the objectives of this study were to visually document differences in the mouthpart morphology of B. l. leucopterus, B. l. hirtus, 
B. insularis, and B. occiduus by using scanning electron microscopy (SEM); to quantify the probing frequencies of B. l. leucopterus, B. l. hirtus, and B. occiduus on selected sorghum; fine fescues (Festuca spp.); St. Augustinegrasses, Stenotaphrum secundatum (Walter) Kuntze; and buffalograsses; and to identify the probing locations of B. l. leucopterus and B. occiduus on resistant and susceptible sorghum and buffalograsses by using a combination of staining, sectioning, and light microscopy techniques.

\section{Materials and Methods}

Mouthpart Morphology. SEM was used to disclose morphological differences in mouthparts among the four chinch bug species. Specimens were prepared for SEM examination following the procedures of HengMoss et al. (2003). Chinch bugs were fixed in 3\% glutaraldehyde in $0.1 \mathrm{M}$ phosphate buffer, $\mathrm{pH} 7.2$, for $2-4 \mathrm{~h}$. After fixation, they were then rinsed four times in the phosphate buffer at 15 min per rinse, postfixed in a solution of $1 \%$ osmium tetroxide in $0.1 \mathrm{M}$ phosphate buffer for 2-4 h, and rinsed three times for 10 min each in double distilled $\mathrm{H}_{2} \mathrm{O}$. Chinch bugs were dehydrated in a series of increasing ethanol dilutions $(25,50,70,95$, and $100 \%)$ for $15-30$ min at each concentration, sputter-coated, and examined at $10 \mathrm{kV}$ with an Amray scanning electron microscope (model \#1810, Amray Inc., Bedford, MA).

The chinch bug proboscis consists of a four-segmented labium that surrounds the mandibular and maxillary stylets. Lengths of the total proboscis and individual segments were measured on five females of each chinch bug species.

In addition, 10 randomly selected labial tip sensilla from each chinch bug species were examined to document differences in size and density of sensilla. The approximate diameter of the bases and tips of the sensilla also was measured. Finally, the mandibular and maxillary stylets were removed from within the labium of previously fixed specimens, sputter-coated, and examined with an SEM to identify structural differences among the four chinch bug species.

An alternative method used to observe chinch bug mandibular and maxillary stylets involved removal of the labium from previously point-mounted and dried specimens, mounting the head on aluminum alloy stubs, gold-coating the head with a Hummer sputtercoater, and examining mouthparts with a Hitachi S-3000N scanning electron microscope (Hitachi, Ltd., Tokyo, Japan) at $10-15 \mathrm{kV}$. This procedure, using previously dried chinch bugs, eliminated the fixation process required when using freshly killed insects.

Probing Frequencies. Three studies were conducted to quantify the probing frequencies of chinch bugs on resistant and susceptible hosts. Study 1 investigated the probing frequency of B. occiduus on four plant species, including the susceptible ' 378 ' buffalograss and resistant Prestige buffalograss, KS94 and 'Wheatland' sorghum, 1139 RC (endophyteenhanced) and $1139 \mathrm{E}$ - (endophyte-free) fine fescue, and 'Floratam' and 'Raleigh' St. Augustinegrass. Study
2 documented the probing frequencies of $B$. occiduus and $B$. l. leucopterus on B. l. leucopterus-resistant (KS94) and -susceptible (Wheatland) sorghum, both of which are resistant to B. occiduus. Finally, Study 3 compared the probing frequencies of $B$. occiduus and B. l. hirtus on $1139 \mathrm{RC}$ and $1139 \mathrm{E}$ - fine fescue, which are susceptible to $B$. $l$. hirtus and resistant to B. occiduus.

Acquisition and Maintenance of Chinch Bugs. B. occiduus were collected with a modified ECHO Shred 'N Vac (model \#2400, ECHO Incorporated, Lake Zurich, IL) from buffalograss 378 (chinch bug-susceptible) research plots at the John Seaton Anderson Turfgrass and Ornamental Research Facility (JSA Research Facility), University of Nebraska Agricultural Research and Development Center, near Mead, NE. Chinch bugs were held under laboratory conditions $\left(26 \pm 3^{\circ} \mathrm{C}\right.$ and a photoperiod of $16: 8$ [L:D] h) for $24 \mathrm{~h}$ to eliminate individuals injured or killed during the collection process, sifted through a 2-mm mesh screen, collected with a battery-powered aspirator, and introduced on to experimental plants.

B. l. leucopterus were collected from infested sorghum at the JSA Research Facility by placing infested plants in plastic bags or by using a modified ECHO Shred 'N Vac to vacuum chinch bugs and plant debris. Collected chinch bugs were processed as described for B. occiduus.

B. $l$. hirtus were collected from infested Kentucky bluegrass, Poa pratensis L. lawns near Columbus, $\mathrm{OH}$, by collaborators at The Ohio State University and shipped to the Department of Entomology at the University of Nebraska-Lincoln. B. l. hirtus were reared and maintained in the greenhouse on $1139 \mathrm{E}$ - (endophyte-free) fine fescue grown in 15 -cm pots containing a potting mixture of sand-soil-peat-perlite in a 2:1:3:3 ratio and maintained under greenhouse conditions $\left(27 \pm 3^{\circ} \mathrm{C}\right.$ and a photoperiod of 16:8 [L:D] h). Plants were watered daily and fertilized weekly with a soluble 20.0:4.4:16.6 (N-P-K) fertilizer. Before experiment initiation, chinch bugs were dislodged from plants, sifted through a 2-mm mesh screen, collected with a battery-powered aspirator, and held in small plastic cups for $24 \mathrm{~h}$.

Acquisition and Maintenance of Plant Material. The plants used in this research were maintained in a University of Nebraska-Lincoln greenhouse at $27 \pm$ $3^{\circ} \mathrm{C}$ under 400-W high-intensity discharge lamps (metal halide) with a photoperiod of 16:8 [L:D] h. Plants were watered daily and fertilized weekly with a soluble 20.0:4.4:16.6 (20N-10P-20K) fertilizer. The potting soil contained a mixture of sand-soil-peatperlite in a $2: 1: 3: 3$ ratio.

B. occiduus-susceptible 378 and -resistant Prestige buffalograsses were obtained from research plots at the JSA Research Facility by extracting sod plugs (10.6 $\mathrm{cm}$ in diameter by $6 \mathrm{~cm}$ in depth). Plugs were potted in $15-\mathrm{cm}$ pots containing the previously described potting mixture and maintained under greenhouse conditions.

Thirty-five by $50-\mathrm{cm}$ flats of Raleigh (B. insularissusceptible) and Floratam (B. insularis-resistant) St. 
Augustinegrasses were acquired from Turfgrass America in Granbury, TX. Approximately 5 by $5-\mathrm{cm}$ sections were transplanted into $15-\mathrm{cm}$ pots and maintained under greenhouse conditions.

Fine fescue tillers of 1139 RC (endophyte-enhanced) and $1139 \mathrm{E}$ - (endophyte-free) were shipped from Rutgers University Plant Science Research Center, Freehold, NJ; potted in 15 -cm pots in the greenhouse upon arrival; and maintained under previously described greenhouse conditions. Endophyte presence was confirmed by Rutgers University Plant Science Research Center before shipping of plant material and again after completion of experiments by using a $0.5 \%$ Rose Bengal staining solution following the protocol of Saha et al. (1988) and also with a Phytoscreen immunoblot kit (catalog no. ENDO7973, Agrinostics, Ltd. Co., Watkinsville, GA).

B. l. leucopterus-resistant KS94 and susceptible Wheatland sorghum seed was obtained from Kansas State University, Manhattan, KS. Seeds were held in cold storage until planting.

Establishment of Experimental Plant Units. Three weeks before introduction of chinch bugs, three sorghum seeds, individual plants of the buffalograsses, St. Augustinegrasses, and fine fescues were planted in 'SC-10 Super Cell' single cell Cone-tainers $(3.8 \mathrm{~cm}$ in diameter by $21 \mathrm{~cm}$ in height, Stuewe \& Sons, Inc., Corvallis, OR). Cone-tainers were maintained under previously described greenhouse conditions. One week before chinch bug introduction, the verdure of all buffalograss, St. Augustinegrass, and fine fescue plants was removed to ensure that all plant material was of similar age. Sorghum seedlings were thinned to one plant per Cone-tainer after germination.

Procedures. Two chinch bugs (fourth and fifth instars) were placed in circular clip-cages $(1.59 \mathrm{~cm}$ in diameter, product \#4008, Converters, Inc., Huntingdon Valley, PA) on plant leaves and allowed to feed for $48 \mathrm{~h}$. Clip-cages were placed near the center of the leaf on 3-wk-old plants (as described previously) and covered with plastic slips to prevent chinch bug escape. Caged areas were excised and prepared following the procedure of Ni and Quisenberry (1997) by using McBride's staining solution consisting of $0.2 \%$ acid fuchsin in 95\% ethanol and glacial acetic acid [1:1 (vol:vol) ]. The stained leaf areas were then placed in a clearing solution consisting of $99 \%$ glycerol, $85 \%$ lactic acid, and double distilled $\mathrm{H}_{2} \mathrm{O}$ [1:1:1 (vol:vol: vol) ] and boiled for $10 \mathrm{~min}$. Leaves were then dehydrated in a series of ethanol dilutions (50, 70, 90, 95, and $100 \%$ ) for $30 \mathrm{~min}$ each, rinsed briefly ( $\approx 5 \mathrm{~min}$ ) in $100 \%$ ethanol, and again in xylene to replace any remaining water residue. Finally, the stained leaf areas were mounted on glass microscope slides with Permount (Sigma, St. Louis, MO), and the stylet tracts within the leaves were examined with a light microscope at $45 \times$ magnification. The number of stylet tracts in each leaf area was recorded.

Design. The experimental design for all studies was completely randomized with 10 replications per treatment. The treatment design for studies 2 and 3 was a
2 by 2 factorial design with two chinch bug species and two plant selections.

Statistical Analysis. Data were analyzed using mixed model analysis (PROC MIXED, SAS Institute 1999) to detect differences in the probing frequency of chinch bugs on the plant treatments. When appropriate, means were separated using Fisher's least significant difference (LSD) procedure. Effects with $P$ values less than or equal to 0.05 were considered significant.

Probing Locations. Buffalograss and sorghum leaves exposed to B. occiduus and B. l. leucopterus were stained and sectioned to facilitate observation of the location and termination points of stylet tracts.

Procedures. Five chinch bugs (fifth instars and adults) were clip-caged to the center of the leaf of 3-wk-old plants (as described previously) and allowed to feed for 3 to $4 \mathrm{~d}$. Chinch bugs were then removed and the caged areas stained with $0.2 \%$ acid fuchsin in double distilled $\mathrm{H}_{2} \mathrm{O}$ for $\approx 12 \mathrm{~h}$. The stained areas were then excised, briefly ( 3 to $4 \mathrm{~s}$ ) rinsed in double distilled $\mathrm{H}_{2} \mathrm{O}$ to remove excess stain, and viewed with a light microscope to locate chinch bug probing sites. Once located, the probed areas were excised, mounted in an embedding matrix (M-1 \#1310, Lipshaw Manufacturing, Pittsburgh, PA), and sectioned with a cryostat. Cross-sections were cut at 14-16 $\mu \mathrm{m}$ and placed on chilled microscope slides. To prevent desiccation, sections were immersed in double distilled $\mathrm{H}_{2} \mathrm{O}$ and covered with a glass slip while being examined and photographically documented at $40 \times$ magnification.

Approximately 50-100 sections of each treatment combination were examined. However, the number of observed sections varied because leaf areas with fewer probes required more sectioning to locate areas with stylet tracts. Probing locations of the two chinch bug species were visually compared on the resistant and susceptible germplasm by using a Zeiss AxioScop (Carl Zeiss MicroImaging, Thornwood, NY) equipped with a built-in digital camera.

\section{Results and Discussion}

Mouthpart Morphology. There were no obvious differences in overall proboscis appearance among the four chinch bug species. However, the lengths of the four individual proboscis segments as well as the total

Table 1. Total proboscis and individual segment measurements (in micrometers) of B. insularis, B. l. leucopterus, B. l. hirtus, and $\boldsymbol{B}$. occiduus

\begin{tabular}{lccccc}
\hline \hline $\begin{array}{c}\text { Chinch bug } \\
\text { species }\end{array}$ & Segment 1 & Segment 2 & Segment 3 & Segment 4 & Total \\
\hline B. insularis & $398 \mathrm{a}$ & $527 \mathrm{a}$ & $366 \mathrm{a}$ & $382 \mathrm{a}$ & $1,673 \mathrm{a}$ \\
B. l. leucopterus & $363 \mathrm{~b}$ & $440 \mathrm{~b}$ & $333 \mathrm{~b}$ & $339 \mathrm{~b}$ & $1,475 \mathrm{~b}$ \\
B. l. hirtus & $355 \mathrm{~b}$ & $418 \mathrm{~b}$ & $327 \mathrm{~b}$ & $339 \mathrm{~b}$ & $1,439 \mathrm{~b}$ \\
B. occiduus & $292 \mathrm{c}$ & $331 \mathrm{c}$ & $245 \mathrm{c}$ & $277 \mathrm{c}$ & $1,145 \mathrm{c}$ \\
\hline
\end{tabular}

Means within the same column followed by the same letter are not significantly different $(P>0.05, \mathrm{LSD}$ test). SE values are 5.0, 8.5, 6.1, 4.5 , and 19.2 for segment $1,2,3,4$, and total, respectively. 

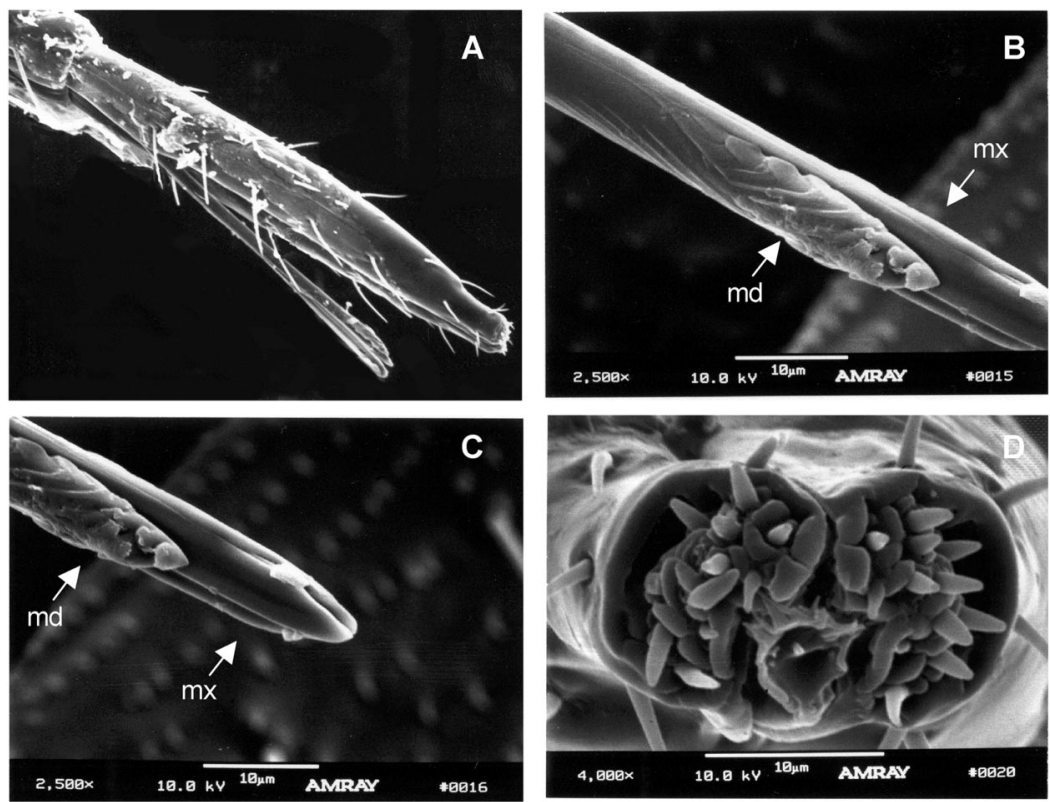

Fig. 1. B. occiduus (A) distal proboscis segment, (B and C) mandibular (md) and maxillary (mx) stylets, and (D) labial tip with sensilla.

length of the mouthparts differed among species (segment $1: F=78.1 ; \mathrm{df}=3,16 ; P<0.0001$; segment $2: F=$ $90.6 ; \mathrm{df}=3,16 ; P<0.0001$; segment $3: F=71.3 ; \mathrm{df}=$ 3,$16 ; P<0.0001$; segment $4: F=90.9 ; \mathrm{df}=3,16 ; P<$ 0.0001; and total: $F=128.6$; $\mathrm{df}=3,16 ; P<0.0001$ ) (Table 1). The total proboscis and individual segment lengths of $B$. insularis were significantly longer than those of B. l. leucopterus, B. l. hirtus, and B. occiduus, but there were no significant differences between the two leucopterus subspecies. These measurements compare favorably with those of Leonard (1968) in his revision of Blissus in eastern North America. The total proboscis and individual segment lengths of $B$. occiduus, however, were significantly shorter than those of all other chinch bug species studied. The subtle differences in mouthpart length and morphology suggest
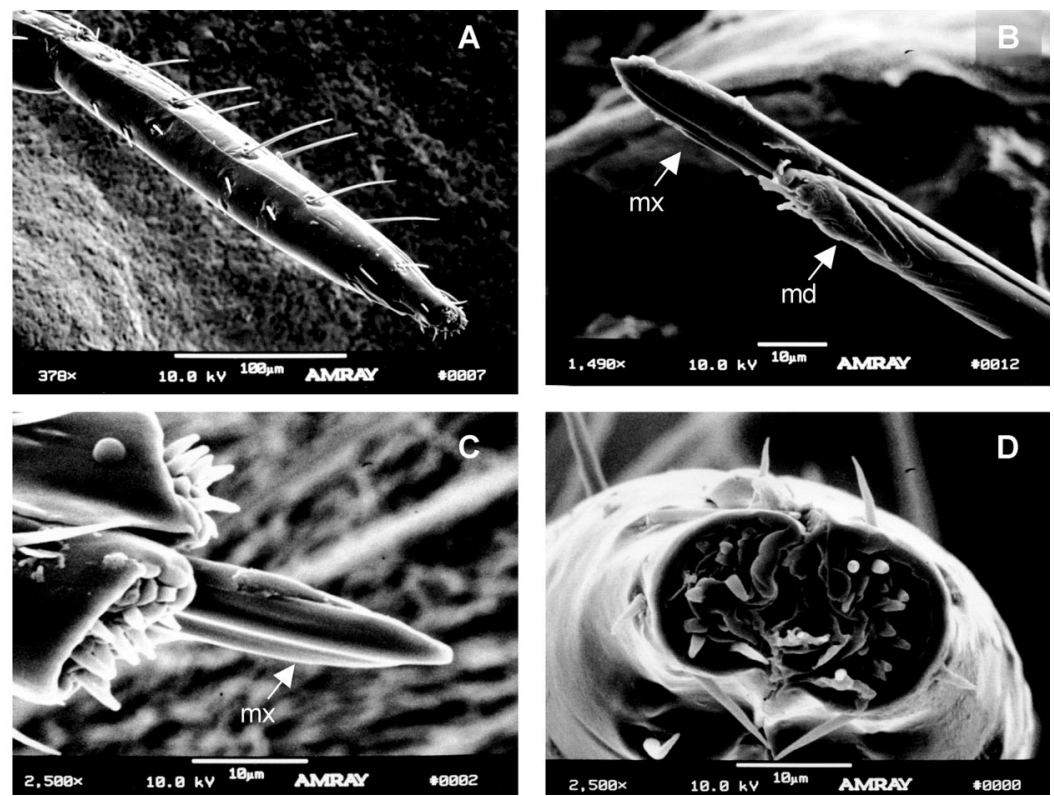

Fig. 2. B. l. leucopterus (A) distal proboscis segment, (B) mandibular (md) and maxillary (mx) stylets, (C) maxillary stylet $(\mathrm{mx})$, and (D) labial tip with sensilla. 

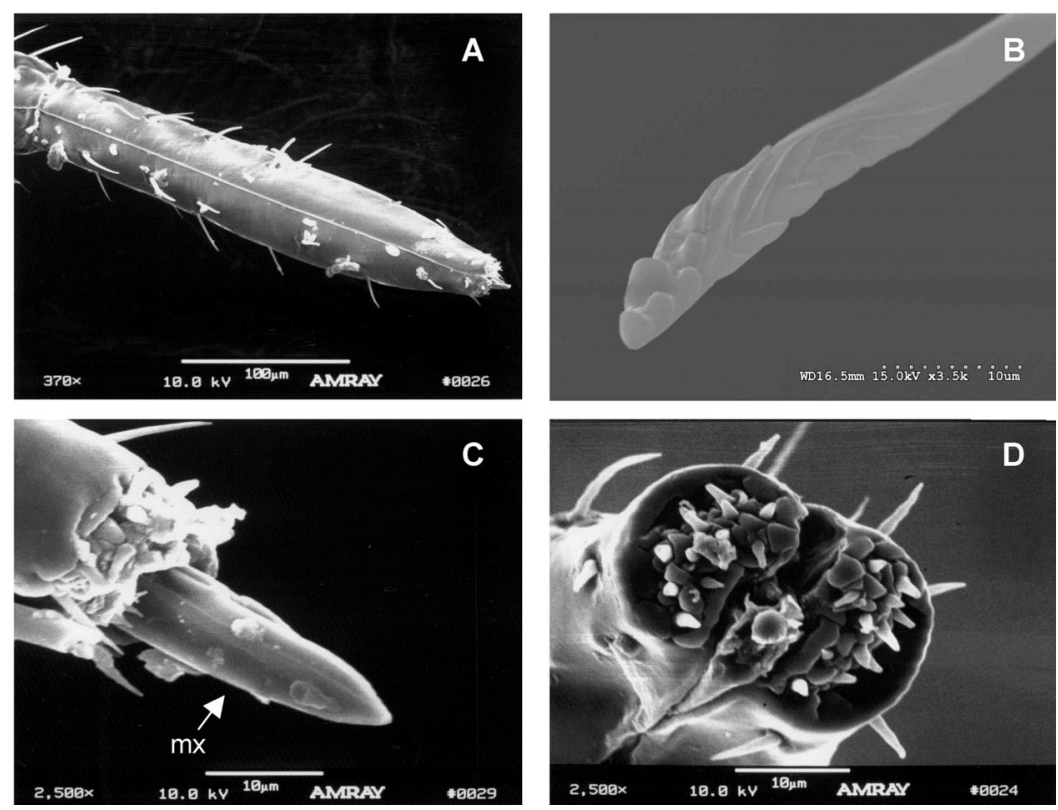

Fig. 3. B. l. hirtus (A) distal proboscis segment, (B) mandibular stylet, (C) maxillary (mx) stylets, and (D) labial tip with sensilla.

that these parameters are unlikely to be the primary factors in the ability of these chinch bugs to differentially feed on and damage plants. A 100- $\mu$ m-thick buffalograss leaf is unlikely to respond much differently to chinch bugs feeding with either 1,200 - or 1,600 $\mu \mathrm{m}$-long stylets.

The mandibular stylet tips were slightly serrated, whereas the tips of the maxillary stylets were sharply pointed (Figs. 1B and C, 2B and C, 3B and C, and 4B and $\mathrm{C}$ ). Although these observations differ slightly from those of Painter (1928), improved microscopy technology, specifically SEM, provided the capability to examine the mouthpart structures with greater magnification.

All four species possessed multiple apical labial sensilla with similar densities and spatial configurations
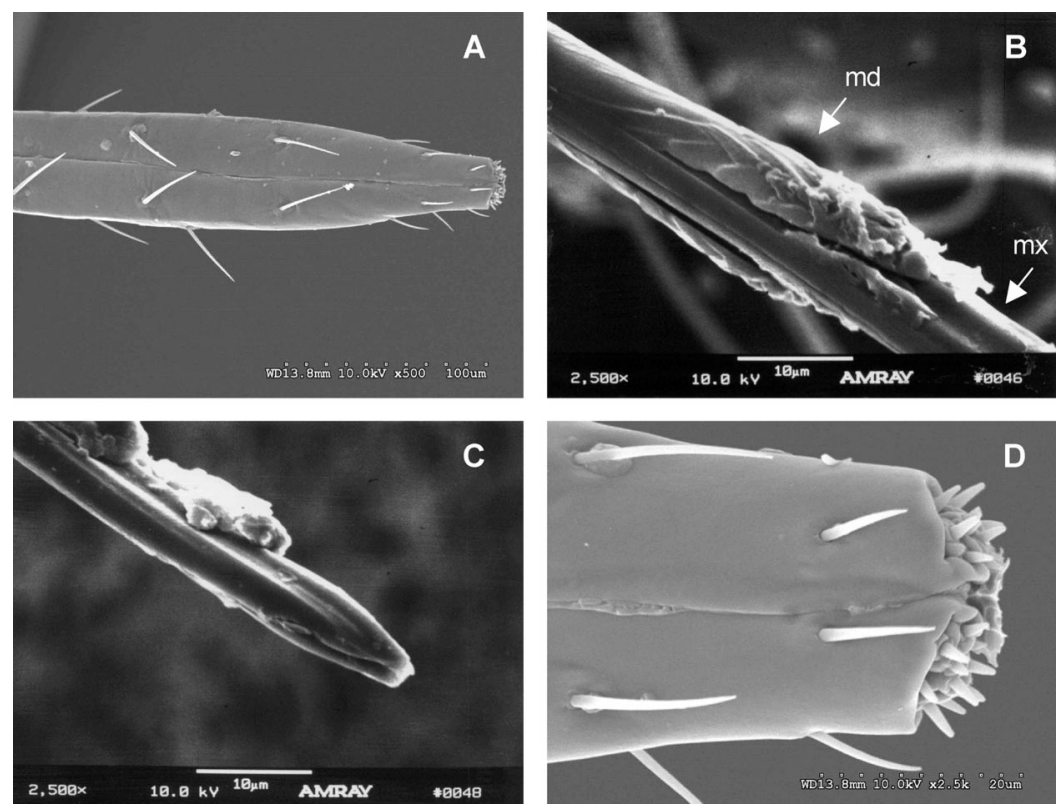

Fig. 4. B. insularis (A) distal proboscis segment, (B) mandibular (md) and maxillary (mx) stylets, (C) maxillary stylet, and (D) labial tip with sensilla. 

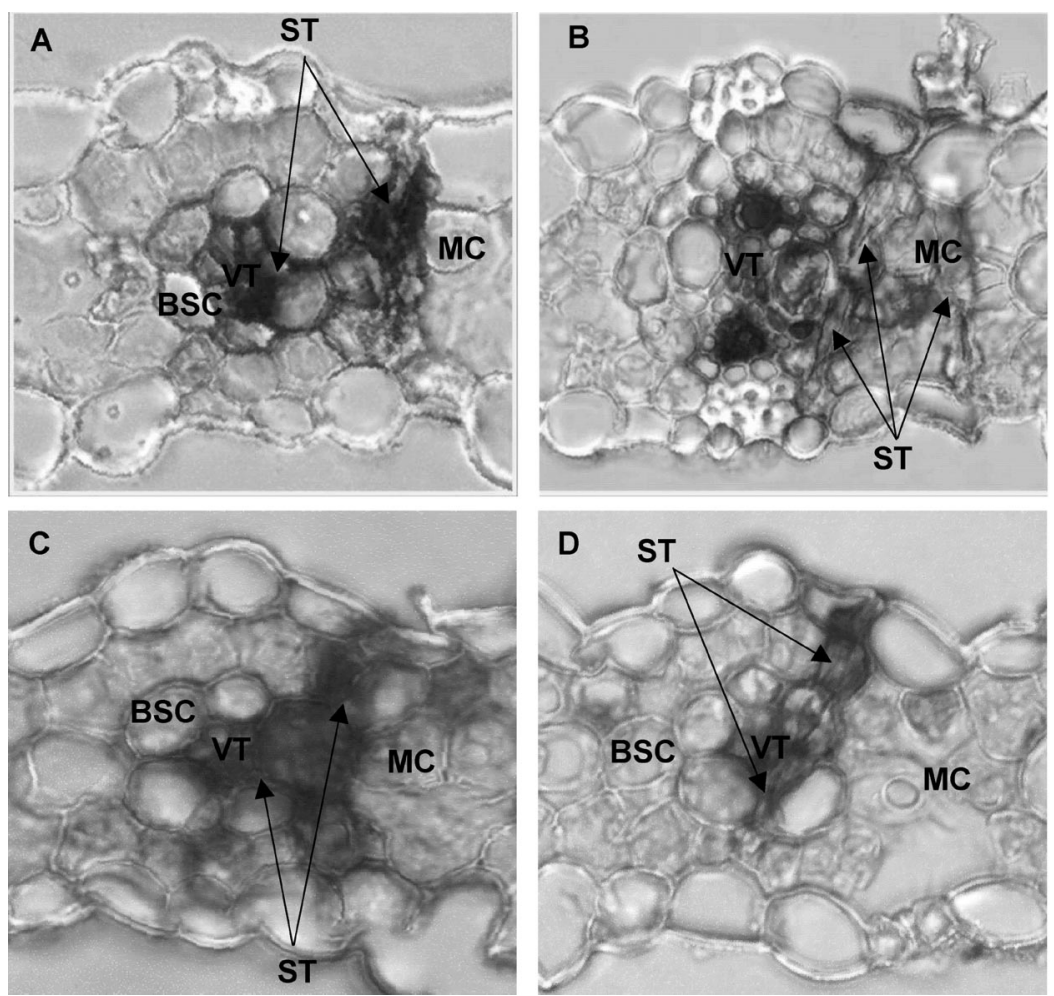

Fig. 5. Stained stylet tracts of (A and B) B. occiduus and (C and D) B. l. leucopterus in Wheatland sorghum. BSC, bundle sheath cells; MC, mesophyll cells; ST, stylet tract; and VT, vascular tissues. Sections (14 $\mu \mathrm{m}$ in thickness) were photographed at $40 \times$ magnification.

(Figs. 1D, 2D, 3D, and 4D). Although statistical differences in sensillar lengths were detected among the species $(F=3.8 ; \mathrm{df}=3,36 ; P=0.02)$, these differences were minimal with sensillar lengths only ranging from $3.0 \pm 0.5$ to $3.9 \pm 0.7 \mu \mathrm{m}$. No differences in sensillar diameter were detected (data not shown). Similar looking apical labial sensilla have been documented in leafhoppers (Backus 1988) and whiteflies (Walker and Gordh 1989), where they have been shown to serve chemosensory functions. Although their function in chinch bug feeding has not been determined, it is likely that they play an integral part in host selection and likely function in chemo- or mechanosensory tasks, or both.

These results represent the first known reports of B. occiduus, B. insularis, and B. l. hirtus mouthpart ultrastructure, and the most recent account of $B . l$. leucopterus mouthpart morphology since the work of Painter (1928).

Probing Frequencies. Study 1. Mixed model analysis detected significant differences $(F=19.3 ; \mathrm{df}=7$, $72 ; P<0.0001$ ) among the probing frequencies of B. occiduus on buffalograss, St. Augustinegrass, fine fescue, and sorghum leaves. B. occiduus probed nearly 3 times as often on buffalograss as on sorghum, and although not significant, numerically more often on the resistant Prestige buffalograss $(62.6 \pm 8.5)$ than on susceptible 378 buffalograss $(52.2 \pm 7.1)$. Probing frequencies on Wheatland and KS94 sorghum (19.5 \pm 6.1 and $19.0 \pm 4.4$, respectively) by B. occiduus were nearly twice that of the probing frequency on Raleigh St. Augustinegrass. However, these differences were not significant. Probing frequencies on the B. occiduus-resistant St. Augustinegrasses Raleigh and Floratam were 10.4 and 2.0, respectively, and although not statistically significant, may provide collaborative evidence of antifeedants in Floratam as reported by Busey and Zaenker (1992). Finally, B. occiduus probed very little on either fine fescue but nearly 8 times more frequently on the endophyte-free (1139 E-) fine fescue than on its endophyte-enhanced counterpart (1139 RC).

B. occiduus probed more frequently on buffalograss than on any other germplasm. However, similar to the findings of Ni and Quisenberry (1997) who studied Russian wheat aphid, Diuraphis noxia (Mordvilko), feeding on wheat, there were no differences in the number of probes between resistant and susceptible buffalograsses.

Study 2. Mixed model analysis indicated significant differences between the probing frequencies of B. occiduus and B. l. leucopterus on both sorghum entries $(F=38.2 ; \mathrm{df}=1,36 ; P<0.001)$. B. l. leucopterus probed $\approx 50 \%$ more often on resistant KS94 (123.0 \pm 

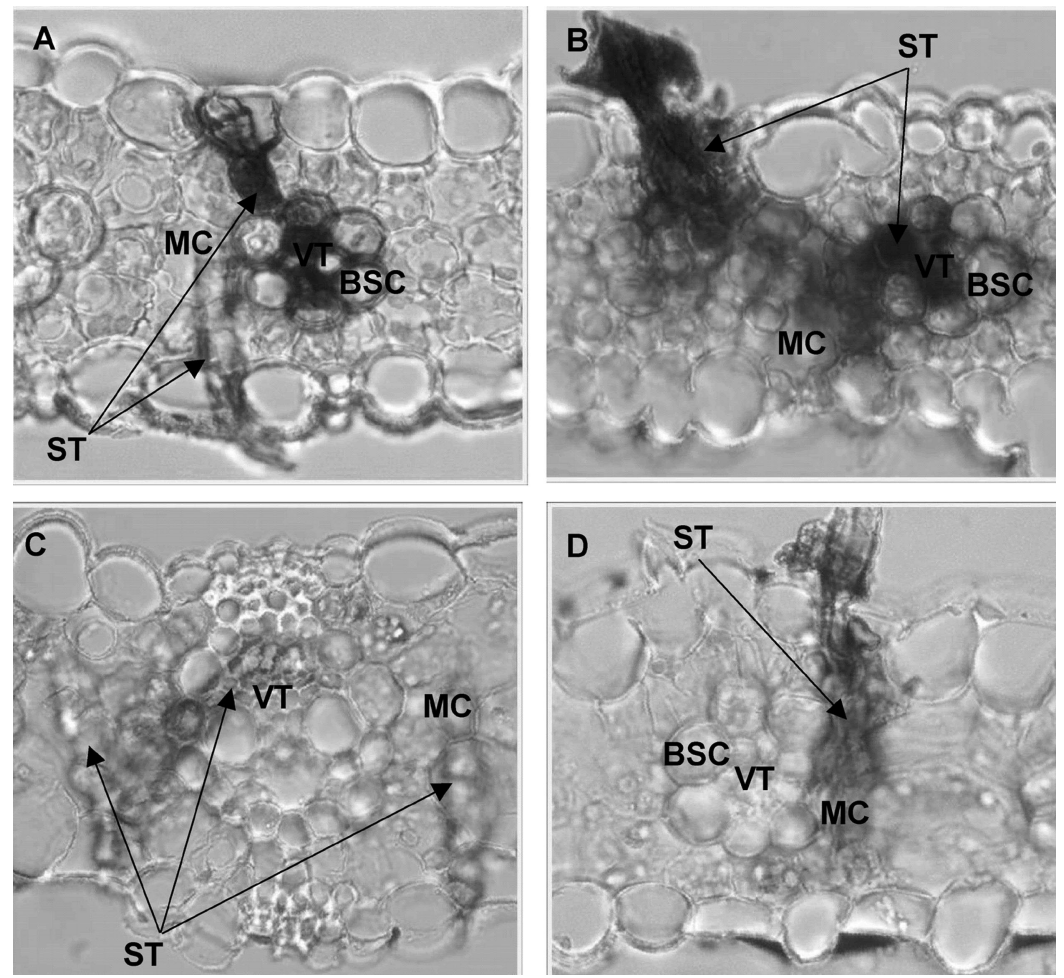

Fig. 6. Stained stylet tracts of (A and B) B. occiduus and (C and D) B. l. leucopterus in KS94 sorghum. BSC, bundle sheath cells; MC, mesophyll cells; ST, stylet tract; and VT, vascular tissues. Sections (14 $\mu \mathrm{m}$ in thickness) were photographed at $40 \times$ magnification.

21.7) than on susceptible Wheatland $(80.0 \pm 13.5)$, whereas the probing frequency of B. occiduus on KS94 $(19.0 \pm 4.4)$ and Wheatland $(19.5 \pm 6.1)$ was similar.

Similar findings have been reported by other researchers. Rafi et al. (1996) and Ogecha et al. (1992) demonstrated that Russian wheat aphids and greenbugs, Schizaphis graninum (Rondani), probed more frequently on resistant than on susceptible plants. The relatively low probing frequency of $B$. occiduus on the two sorghum entries in this study may indicate that sorghum is not a preferred host of B. occiduus.

Study 3. Mixed model analysis detected significant differences between the probing frequencies of B. occiduus and B. l. hirtus on endophyte-free $1139 \mathrm{E}-$ and endophyte-enhanced $1139 \mathrm{RC}$ fine fescues. B. $l$. hirtus probed significantly more often than $B$. occiduus on either fine fescues $(F=21.4 ; \mathrm{df}=1,36 ; P<0.0001)$, whereas both chinch bug species probed significantly more on the endophyte-free $1139 \mathrm{E}$ - than the endophyte-enhanced $1139 \mathrm{RC}$ fine fescue $(F=7.4 ; \mathrm{df}=1$, $36 ; P=0.01)$. B. l. hirtus probed $29.3 \pm 5.5$ and $18.9 \pm$ 4.2 times on $1139 \mathrm{E}$ - and $1139 \mathrm{RC}$, respectively, whereas $B$. occiduus probed only $11.7 \pm 2.9$ and $1.5 \pm$ 0.8 times on the same plants.

These results suggest that the endophyte may have deterred chinch bug feeding because the probing frequency of B. l. hirtus and B. occiduus was higher on the endophyte-free fine fescue. These results concur with those of Carrière et al. (1998) who found that compounds produced by the endophytes reduce insect herbivory. In general, endophyte-enhanced perennial ryegrasses, fine fescues, and tall fescues are highly resistant to chinch bug feeding (Saha et al. 1987, Mathias et al. 1990, Carrière et al. 1998, Richmond and Shetlar 2000, Yue et al. 2000).

Probing Locations. Probing locations of B. occiduus and B. l. leucopterus differed on Wheatland sorghum, which is resistant to $B$. occiduus but susceptible to B. l. leucopterus. The stylet tracts of B. occiduus terminated in the vascular tissues (VT) approximately twice as often as bundle sheath cells (BSC) and mesophyll cells (MC) (Fig. 5A and B). In contrast, the stylet tracts of B. l. leucopterus terminated more frequently in the BSC, although they also penetrated the VT (Fig. 5C and D).

Probing locations of B. occiduus and B. l. leucopterus were similar on KS94, which is resistant to both chinch bug species. Stylet tracts of both species terminated in the VT of the resistant sorghum $\approx 50 \%$ more often than any other area. The BSC and MC also were probed by both chinch bug species (Fig. 6).

These observations suggest that most injury to sorghum occurs when chinch bug stylets tracts probe in the BSC, which are important in carrying out functions necessary for photosynthesis in $\mathrm{C}_{4}$ plants (Sage and Monson 1999). Under normal light conditions, the 

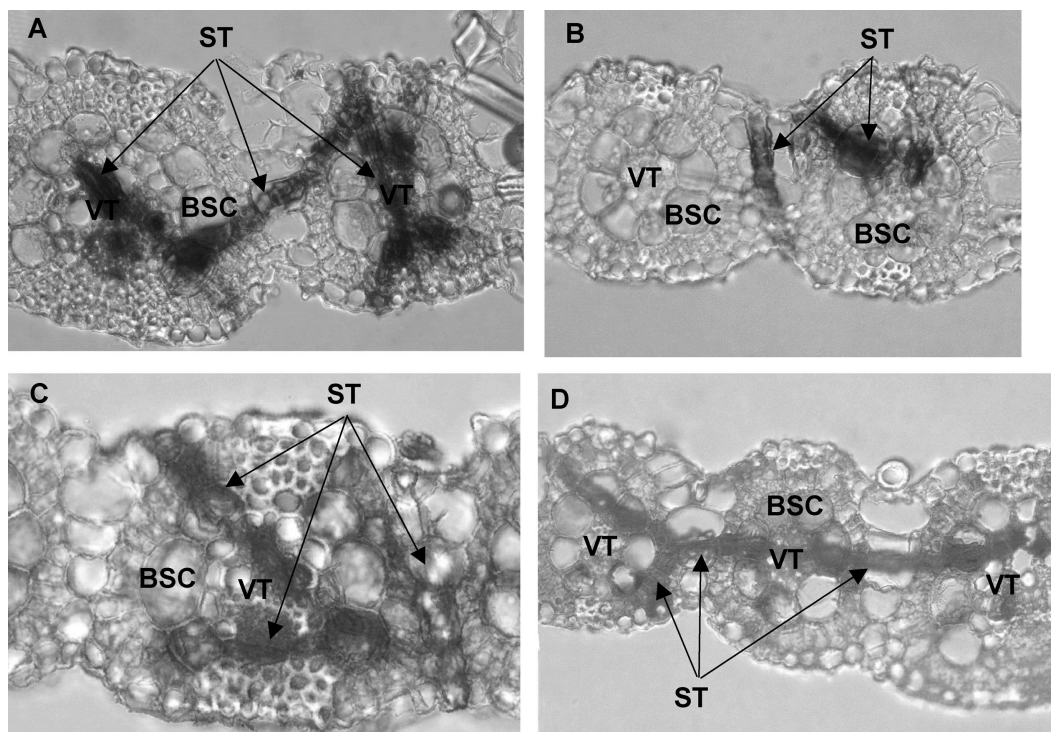

Fig. 7. Stained stylet tracts of (A and B) B. occiduus and (C and D) B. l. leucopterus in 378 buffalograss. BSC, bundle sheath cells; ST, stylet tract; and VT, vascular tissues. Sections (14 $\mu \mathrm{m}$ in thickness) were photographed at $40 \times$ magnification.

BSC contain significant amounts of starch and carbohydrates that make them an ideal food source for piercing-sucking insects (Sage and Monson 1999). Although these observations suggest that feeding lo- cations may play an important role in the susceptibility or resistance, the influence of probing frequency and duration cannot be discounted. Further studies investigating these factors as well as the function of chinch
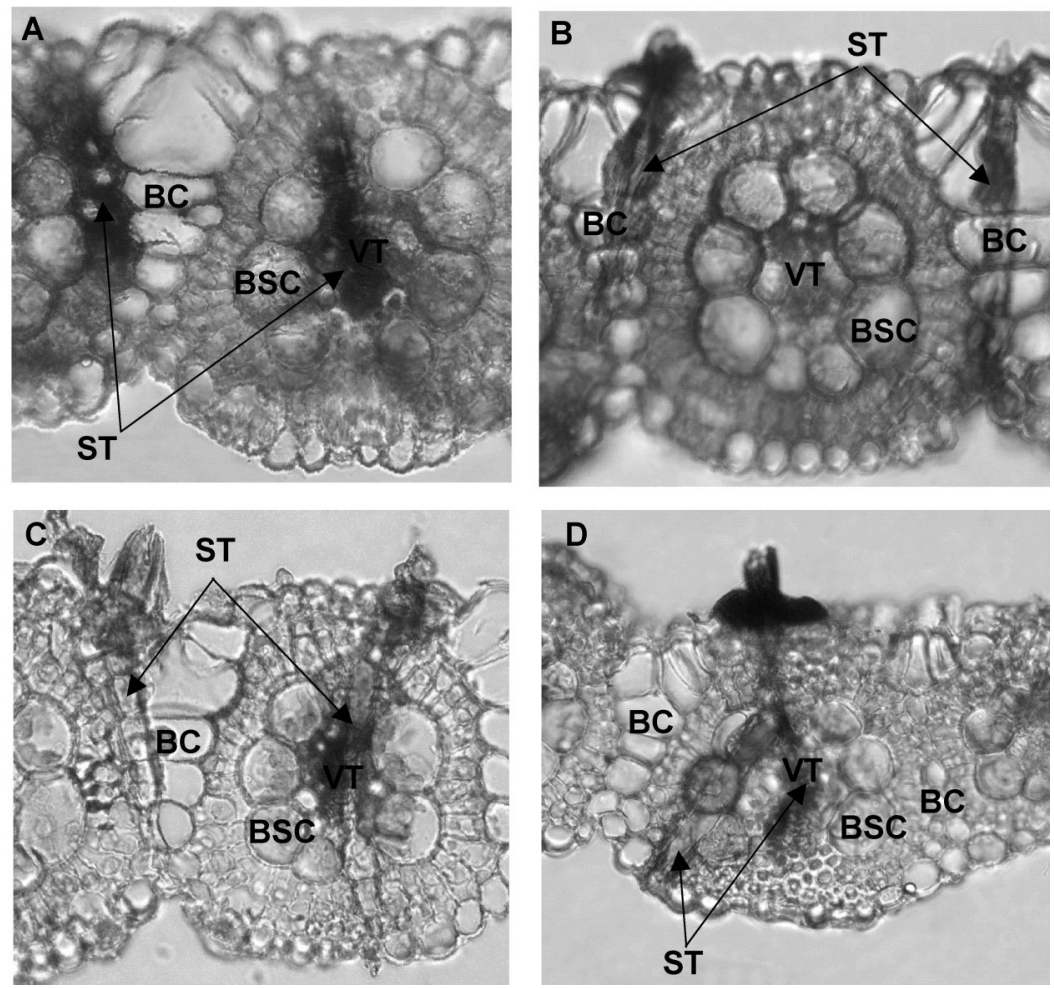

Fig. 8. Stained stylet tracts of (A and B) B. occiduus and (C and D) B. l. leucopterus in Prestige buffalograss. BC, bulliform cells; BSC, bundle sheath cells; ST, stylet tract; and VT, vascular tissues. Sections (14 $\mu \mathrm{m}$ in thickness) were photographed at $40 \times$ magnification. 
bug salivary components and the responses of the plants to chinch bug feeding would be valuable.

The stylet tracts of B. occiduus and B. l. leucopterus most often terminated in the VT of 378 buffalograss (Fig. 7), which is susceptible to both chinch bug species. The BSC also were probed by both $B$. occiduus and B. l. leucopterus, with stylet tracts frequently terminating on the opposite side of the leaf. However, the stylet tracts of B. l. leucopterus were often much longer, 200-300 $\mu \mathrm{m}$, than the tracts of B. occiduus which typically reached lengths of only $\approx 100 \mu \mathrm{m}$. B. l. leucopterus stylet tracts often penetrated one or two vascular bundles before terminating.

Chinch bug probing locations on Prestige (resistant to B. occiduus but susceptible to B. l. leucopterus) were similar to those observed on 378 buffalograss. Stylet tract termination sites were predominantly in the VT and bulliform cells (BC) (Fig. 8). The BC, which allow plants to conserve water during periods of moisture stress (Sage and Monson 1999) may serve as an important source of water for chinch bugs, which thrive in hot, dry conditions. B. occiduus and B. l. leucopterus occasionally probed in the BSC.

The results of this study indicate that feeding location on buffalograss is unlikely to be the primary factor in the ability of these chinch bugs to differentially feed on and damage plants as stylet tracts terminated in the VT, BSC, and BC. Again, the potential effects of probing frequency and duration, salivary secretions, plant defense responses to chinch bug feeding, and their interactions should not be discounted.

Further research is needed to explore the specific feeding mechanisms of chinch bugs. Electronic feeding monitoring techniques (McLean and Weigt 1968) would contribute new information on probing durations on resistant and susceptible germplasm as well as those of different chinch bug species on the same germplasm. Transmission electron microscopy (TEM) would provide additional details on the feeding locations of chinch bugs on resistant and susceptible hosts. TEM also may be a useful tool in determining the function(s) of apical labial sensilla as mechano- or chemosensory based on the innervations of dendrites and structure of the sensilla (Walker and Gordh 1989). This information, in conjunction with behavioral studies, may provide insights into chinch bug host selection. Finally, it has been speculated that chinch bugs, and other sap-feeding insects, possess salivary toxins (Baxendale et al. 2002). Identifying and characterizing chinch bug salivary secretions, and documenting differences among the chinch bug species, would be valuable. This information may help us understand the differences observed in the susceptibility or resistance among the grasses to feeding by the various chinch bug species.

\section{Acknowledgments}

We thank Tom Eickhoff, Ellen Paparozzi, and Liz Conley (University of Nebraska) for technical assistance. We also thank Stacy Bonos (Rutgers University), John Reese (Kansas State University), and Turfgrass America for germplasm as well as David Shetlar (The Ohio State University) and Dennis Hoffman (Texas A\&M University) for providing chinch bugs not locally available. We acknowledge Kenneth Vogel and Terrance Riordan for reviewing this manuscript. This research was supported in part by the University of Nebraska Agriculture Experiment Station Project 17-078, the United States Golf Association and International Turfgrass Producers. This is paper number 14521 of the journal series of the Agricultural Research Division, University of NebraskaLincoln.

\section{References Cited}

Anderson, W. G. 2004. Evaluation of cool- and warm-season grasses for resistance to multiple chinch bug species. M.S. thesis, University of Nebraska, Lincoln, NE.

Backus, E. A., and D. L. McLean. 1982. The sensory systems and feeding behavior of leafhoppers. I. The aster leafhopper, Macrosteles fascifrons Stahl (Homoptera: Cicadellidae). J. Morphol. 172: 3-14.

Backus, E. A., and D. L. McLean. 1985. Behavioral evidence that the precibarial sensilla of leafhoppers are chemosensory and function in host discrimination. Entomol. Exp. Appl. 37: 219-228.

Backus, E. A. 1988. Sensory systems and behaviors which mediate hemipteran plant-feeding: a taxonomic overview. J. Insect. Physiol. 34: 151-165.

Baxendale, F. P., T. E. Eickhoff, and T. M. Heng-Moss. 2002. Chinch bugs in buffalograss and zoysiagrass turf. Coop. Ext., Univ. Nebr.-Lincoln NF97-342.

Busey, P., and E. I. Zaenker. 1992. Resistance bioassay from southern chinch bug (Heteroptera: Lygaeidae) excreta. J. Econ. Entomol. 85: 2032-2038.

Carrière, Y., A Bouchard, S. Bourassa, and J. Brodeur. 1998. Effect of endophyte incidence in perennial ryegrass on distribution, host-choice, and performance of the hairy chinch bug (Hemiptera: Lygaeidae). J. Econ. Entomol. 91: $324-328$.

Heng-Moss, T. M., F. P. Baxendale, T. P. Riordan, L. Young, and K. Lee. 2003. Chinch bug resistant buffalograss: an investigation of tolerance, antixenosis, and antibiosis. J. Econ. Entomol. 96: 1942-1951.

Leonard, D. E. 1968. A revision of the genus Blissus (Heteroptera: Lygaeidae) in eastern North America. Ann. Entomol. Soc. Am. 61: 239-250.

Mathias, J. K., R. H. Ratcliffe, and J. L. Hellman. 1990. Association of an endophytic fungus in perennial ryegrass and resistance to the hairy chinch bug (Hemiptera: Lygaeidae). J. Econ. Entomol. 83: 1640-1645.

McLean, D. L., and W. A. Weigt, Jr. 1968. An electronic measuring system to record aphid salivation and ingestion. Ann. Entomol. Soc. Am. 61: 180-185.

Ni, X., and S. Quisenberry. 1997. Distribution of Russian wheat aphid (Homoptera: Aphididae) salivary sheaths in resistant and susceptible wheat leaves. J. Econ. Entomol. 90: $848-853$.

Ogecha, J., J. A. Webster, and D. C. Peters. 1992. Feeding behavior and development of biotypes E, G, and $\mathrm{H}$ of Schizaphis graminum (Homoptera: Aphididae) on 'Wintermalt' and 'Post' barley. J. Econ. Entomol. 85: 15221526.

Painter, R. H. 1928. Notes on the injury to plant cell by chinch bug feeding. Ann. Entomol. Soc. Am. 21: 232-242.

Parrish, W. B. 1967. The origin, morphology, and innervation of aphid stylets (Homoptera). Ann. Entomol. Soc. Am. 60: 273-276.

Rafi, M. M., R. S. Zemetra, and S. S. Quisenberry. 1996. Interaction between Russian wheat aphid (Homoptera: 
Aphididae) and resistant and susceptible genotypes of wheat. J. Econ. Entomol. 89: 239-246.

Richmond, D. S., and D. J. Shetlar. 2000. Hairy chinch bug (Hemiptera: Lygaeidae) damage, population, density, and movement in relation to the incidence of perennial ryegrass infected by Neotyphodium endophytes. J. Econ. Entomol. 93: 1167-1172.

Sage, R. F., and R. K. Monson. 1999. $\mathrm{C}_{4}$ plant biology. Academic, San Diego, CA.

Saha, D. C., J. M. Johnson-Cicalese, P. M. Halisky, M. I. Van Heemstra, and C. R. Funk. 1987. Occurrence and significance of entophytic fungi in the fine fescues. Plant Dis. 71: 1021-1024.

Saha, D. C., M. A. Jackson, and J. M. Johnson-Cicalese. 1988. A rapid staining method for detection of endophytic fungi in turf and forage grasses. Phytopathology 78: 237-239.

SAS Institute. 1999. SAS/STAT software: changes and enhancements through release 8.2. SAS Institute, Cary, NC.
Saxena, P. N., and H. L. Chada. 1971. The greenbug, Schizaphis graminum. 1. Mouth parts and feeding habits. Ann. Entomol. Soc. Am. 64: 897-904.

Vittum, P. J., M. G. Villani, and H. Tashiro. 1999. Turfgrass Insects of the United States and Canada, 2nd ed. Cornell University Press. Ithaca, NY.

Walker, G. P., and G. Gordh. 1989. The occurrence of apical labial sensilla in the Aleyrodidae and evidence for a contact chemosensory function. Entomol. Exp. Appl. 51: 215224.

Yue, Q., J. Johnson-Cicalese, T. J. Gianfagna, and W. A. Meyer. 2000. Alkaloid production and chinch bug resistance in endophyte-inoculated chewings and strong creeping red fescues. J. Chem. Ecol. 26: 279-292.

Received 12 May 2005; accepted 19 October 2005 